\title{
The Heart of Forgiveness
}

\author{
Arthur P Ciaramicoli* \\ Clinical Psychologist, USA
}

Submission: April 14, 2017; Published: April 18, 2017

*Corresponding author: Arthur P Ciaramicoli, Clinical Psychologist, USA, Tel: 508-435-9535; Email: drarthurc@gmail.com

\section{Perspective}

When we think about forgiveness we often think of something we confer on others- I forgive you. In truth we cannot forgive others without understanding our difficulties in forgiving ourselves. Forgiving oneself for addictive behavior is immensely difficult; alcohol, heroin or your drug of choice pulled you away from the world of the living. When you enter into a full time relationship with drugs your human relationships fade in importance. Addictions do this to people, regardless of who you are or where you came from. Do not allow your world to become narrow, for your shame and grief for the pain you have caused can make you avoid the very people you need the most. It is quite possible, if you are open to a process that involves acceptance of human frailty and imperfections, to forgive yourself. I have seen people return from the abyss of shame and guilt to a position of understanding and forgiveness thousands of time.

When we deepen our understanding of human nature our view of the world and ourselves widens. From this perspective we discover forgiveness for ourselves and others. Forgiveness is an unfolding process rather than an act that is completed and set aside. Forgiveness comes slowly, as we continue to learn from the tragedies and traumas of the past in a continual effort to transcend them and return to a positive view of ourselves. With time, determination and effort we move forward, understanding the past rather than endlessly repeating it.

\section{Perception}

Our perceptions are limited by our experiences and our interpretations of our experiences. Most people who cannot forgive themselves have developed a critical self-voice that holds them to unrealistic expectations. If you have been criticized, ignored or shown little compassion in your life you have likely learned to blame yourself excessively for mistakes and errors in judgment. In addition if those around you do not understand the complexities of addiction you have probably been subjected to miss-understandings that have fueled a critical self-voice. On the other hand, people who have been fortunate enough to be supported by those who do understand the complications of addiction, whether it is family members, friends or addiction counselors have received the necessary empathy and understanding that encourages forgiveness, without the burden of guilt that exacerbates addictive transgressions.

\section{Criticizing vs. Understanding}

Every time we demean another person for their imperfections we re-visit the times' the same behavior was done to us. By repeating this behavior we unfairly punish others for the lack of understanding we received, and in this process we cement our inability to free ourselves and treat others kindly. In order to forgive yourself you have to turn inwardly and begin to understand how you came to be so hard on yourself. Instead of blaming yourself for irrational behavior while under the influence or simply for human errors it is necessary to realize that no child is born with a critical self-voice. The environment you were exposed to created your demeaning voice, complicated by your using days. Now it is time to seek a more accurate view of you. Forgiveness arises through the hard work of empathy. Seeking to understand, opening our minds and our hearts to what was once hidden from view, we see a view of our self we could not see before, and in that widened perspective, we see others with the same empathy and open mindedness as we now see our self. You no longer torment yourself with thoughts of what you should have done or should have said but rather see the truth of who you are today and that is finally enough.

\section{Transformation}

The change from a critical self-voice to an understanding self-voice is a transformation of the highest proportions. Kindness toward others is much easier than kindness toward oneself. When your internal voice is reasonable and fair your heart opens up to the world, we move outward from self toward others. This new understanding allows us to feel closer to those we previously judged, a defense used in order to create protective distance. We no longer need to be harsh toward others to shield ourselves. We no longer need to punish ourselves for actions under the influence, we take responsibility but we do not adhere 
to relentless name calling for what we now understand and will likely not repeat. We are committed to learning from the tragedies and traumas of the past in an ongoing effort to transcend them. With this formula we are able to move forward, building on the past rather than endlessly repeating it. Forgiveness is the ultimate act of connectedness. In forgiving yourself you forgive others and are far less critical internally and externally. The world then becomes a kinder, warmer place. Forgiveness now signifies freedom-releasing resentment, bitterness and prideallowing us to live with ease within, and to love others with uncritical affection.
Your next submission with Juniper Publishers will reach you the below assets

- Quality Editorial service

- Swift Peer Review

- Reprints availability

- E-prints Service

- Manuscript Podcast for convenient understanding

- Global attainment for your research

- Manuscript accessibility in different formats

( Pdf, E-pub, Full Text, Audio)

- Unceasing customer service

Track the below URL for one-step submission https://juniperpublishers.com/online-submission.php 